\title{
Effects of Phthalate/Adipate Esters Exposure during Perinatal Period on Reproductive Function after Maturation in Rats
}

\author{
H. C. Lee*, Y. G. Ko*, G. S. Im*, H. J. Chung*, H. H. Seong*, W. K. Chang*, \\ K. Yamanouchi** and M. Nishihara** \\ National Livestock Research Institute, RDA*, \\ Department of Veterinary Physiology, Tokyo University, Tokyo, Japan**
성숙한 랫트의 번식 기능에 있어 프탈레이트/아디페이트 에스테르의 주산기 노출의 영향 \\ 이휘철* • 고응규* • 임기순* · 정학재* - 성환후* • 장원경* • K. Yamanouchi** • M. Nishihara** \\ 농촌진흥청 축산연구소*, 동경대학교 수의생리학교실**
}

요 약

프탈레이트 에스테르는 플라스틱 가소제로서 이용되며 또한 유제품과 같은 음식에서 미량으로 발 견되고, 종종 내분비 교란물질로 의심되고 있다. 본 연구의 목적은 DBP, DINP 또는 DEHA의 주산기 노출이 랫트에 있어 성 성숙 후, 번식기능 특히 뇌의 성분화에 어떤 영향을 끼치는 지에 대해 조사하 였다. 이를 수행하기 위해서, 어미에게 식물성 에스트로겐의 함유가 낮은 분말 사료에 다음과 같은 단계적 농도의 DBP (20, 200, 2000, $10000 \mathrm{ppm})$, DINP (40, 400, 4000, $20000 \mathrm{ppm})$, DEHA (480, 2400, $12000 \mathrm{ppm}$ )를 혼합한 후, 임신 15일째부터 출생 후, 21일째 (이유기)까지 섭취 시켰고, 성 성숙 후, 혈 청 성호르몬 및 성선자극호르몬의 레벨과 교배행동 및 성주기 회귀를 분석하였다. 그 결과, DBP, DINP 또는 DEHA의 주산기 노출에 의한 생후 20 21주째의 암수 랫트에 있어, 성호르몬 및 성선자극 호르몬의 레벨뿐만 아니라 암컷의 성주기의 회귀에 대해 어떠한 영향을 주지 않았다. 이것은 시상하 부-하수체-성선축의 내분비계를 제어하는 뇌의 성분화에는 이들 화학물질이 영향을 주지 않았다는 사실을 시사한다. 하지만, 수컷의 성행동 특히, 사정 (ejaculation)과 암컷의 로도시스 반응이 억제되는 것이 관찰되었다. 이러한 결과로부터 DBP, DINP 또는 DEHA의 주산기 노출은 성선자극 호르몬의 분 비에는 영향을 주지 않지만, 성행동을 제어하는 시상하부의 어떤 영역에 직접적으로 작용할 가능성 즉, 뇌의 성분화에 영향을 끼쳐 성 성숙 후, 성 특이적 행동을 억제시킬 가능성을 시사한다.

(주요어: 아디페이트, 성선자극호르몬, 프탈레이트, 성행동, 성스테로이드 호르몬)

\section{I . INTRODUCTION}

Testosterone, or its metabolite estradiol generated by aromatase enzyme activity, acts on the brain to induce masculine patterns of development that result in sex differences in reproductive behaviors and gonadotrophin feedback control mechanisms. It is well established that this behavioral sexual dimorphism is determined at least in part by exposure to androgen during the critical period for sexual differentiation of neural tissue (MacLusky and Naftolin, 1981). The critical period in rats begins in late gestation and continues into the first week to 10 days of postnatal life (MacLusky and Naftolin, 1981). The increase in developmental and functional disorders of the male reproductive

Corresponding author : Masugi Nishihara, D.V.M., Ph.D. Department of Veterinary Physiology, Veterinary Medical Science, The University of Tokyo, 1-1-1 Yayoi, Bunkyo-ku, Tokyo 113-8657, Japan. Tel : +81-3-5841-5386, Fax : +81-3-5841-8017, E-mail: amnishi@mail.ecc.u-tokyo.ac.jp 
tract in both humans and wildlife have led to the hypothesis that perinatal exposure to environmental chemicals may be harmful to normal development of the male reproductive tract by disrupting the endocrine system (Toppari et al., 1996; Colborn, 1996).

Endocrine disrupting chemicals (EDCs) include a number of environmental chemicals that interact with an endocrine system, often due to their activity as a hormonal mimic (Waldron and Naber, 1974). The majority of EDCs are recognized to bind estrogen receptors, which are members of a family of ligand-activated proteins that serve as transcriptional factors for a wide variety of cellular target genes, and act as agonists or antagonists of estrogen (Barlow et al., 1999; Colborn et al., 1993). During recent years the phthalates have attracted much attention because several of these compounds are suspected of possessing endocrine disrupting effects. Phthalate esters are used as plasticizers and also found at low levels in foods, particularly fatty foods such as dairy products because they are fat-soluble (Sharman et al., 1994; Page and Lacroix, 1995).

Di-n-butyl phthalate (DBP) initially attracted attention as the potential EDCs because it was found to be a weak estrogen receptor agonist in some cell-based assays (Harris et al., 1997; Jobling et al., 1995). Several studies suggested that DBP may disrupt the endocrine system and may produce marked alterations during male reproductive organ development (Gray et al., 2001; Mylchreest et al., 1999 and 2000). The effects are also closely associated with the antiandrogenic activity produced by DBP on developing fetuses and newborn (Sharpe et al., 1995; Wine et al., 1997). As for diisononyl phthalate (DINP), the most common findings in rodents are liver and kidney enlargement and increased levels of peroxisomal enzymes (Lington et al., 1997), and thus DINP is recognized to have peroxisome proliferator properties. In utero exposure to DBP (Mylchreest et al., 1999; Gray et al., 1999), DINP (Gray et al., 2000) and di-2ethylhexyl phthalate (DEHP) (Gray et al., 1999; Arcadi et al., 1998) has been shown to disrupt differentiation of androgen-dependent tissues in male rat offspring. Since some phthalates have testis toxicity and antiandrogenic effects, alternative compounds, di-2-ethylhexyl adipate (DEHA), have replaced phthalates as plasticizers in flexible polyvinyl chloride (PVC) products (Petersen and Breindahl, 1998). Although DEHA is currently being evaluated as potential substitutions for some phthalates, due to similarities in structure (Fig. 1) and metabolism of DINP, DEHP and DEHA, it could be hypothesized that similarities in action may also exist.

In the present study, we assessed the effects of perinatal exposure to DBP, DINP and DEHA on several aspects of reproductive function in rats, especially their effects on sexual differentiation of the brain. To this end, maternal rats were given a diet containing these chemicals from gestational day 15 to the day of weaning, and the sexual behaviors, gonadotropin levels and estrous cyclicity were examined after maturation.
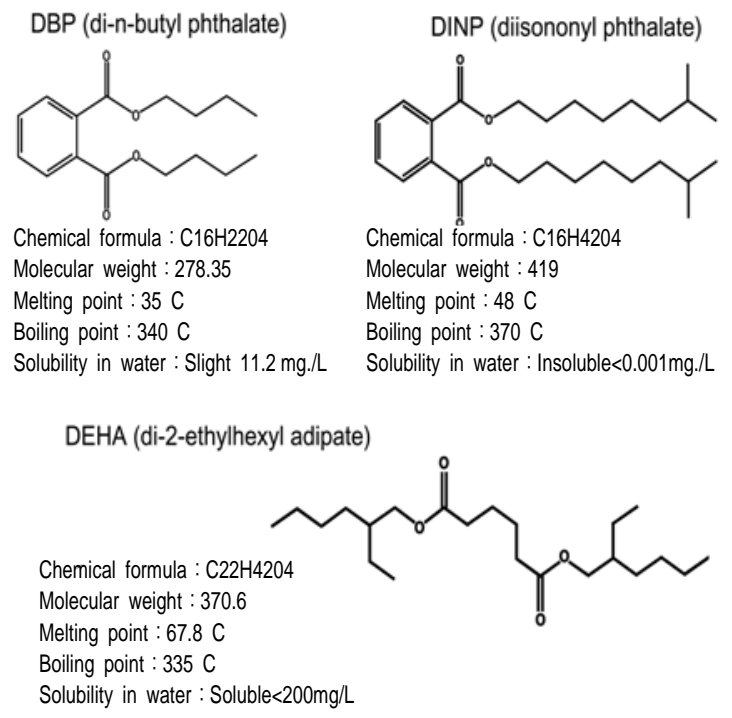

Fig. 1. Chemical structure and physiochemical properties of DBP, DINP and DEHA. 


\section{MATERIALS \& METHODS}

\section{Test compounds}

DBP (CAS No. 84-74-2, purity $>98 \%$, Cat No. P0292) from Tokyo Kasei Kogyo Co. Ltd. (Tokyo, Japan), DINP (CAS No. 28553-12-0, purity $>98 \%$, Cat No. 040-22805), and DEHA (CAS No. 103-23-1, purity $>99 \%$, Cat No. 02713006) from Wako Pure Chemical Industries Ltd. (Osaka, Japan) were purchased.

\section{Animals and treatments}

This study followed Guidelines for the Care and Use of Laboratory Animals of the Graduate School of Agricultural and Life Sciences, the University of Tokyo. Wistar-Imamichi rats (Imamichi Institute for animal Reproduction, Ibaraki, Japan) of approximately 8 weeks of age were obtained and maintained in a room with controlled illumination (lights on 0500-1900 hr) and temperature (23 \pm $1^{\circ} \mathrm{C}$ ), and provided chow and water ad libitum. Animals were mated (mating confirmed by sperm presence in vaginal smears), and the day of mating was designated as gestational day (GD) 0 . The pregnant females were allowed to deliver pups naturally (day of birth = PND 0), and the litter size was adjusted to eight on the PND 5. Some of the pups born from the control diet-dams were subcutaneously injected with 20 $\mu \mathrm{g}$ estradiol benzoate (EB; Sigma) or $10 \mathrm{mg}$ testosterone propionate (TP; Sigma) in $50 \mu \mathrm{l}$ sesame oil on PND 2. The dams were fed with pulverized soy-free diet (NIH-07-PLD (phytoestrogenlow diet); Oriental yeast Co. Ltd., Tokyo, Japan) to reduce the effect of phytoestrogen. From GD 15 to the day of weaning (PND 21), the dams were provided with pulverized soy-free diet that contained 20, 200, 2,000 and 10,000 ppm of DBP, $40,400,4,000$ and 20,000 ppm of DINP, or 480, 2,400 and 12,000 ppm of DEHA. After weaning, all the animals were fed with a conventional pellet diet (CRF-1; Oriental yeast Co. Ltd., Tokyo, Japan).

\section{Experimental design}

After maturation, estrous cyclicity of females was examined by daily microscopic observation of vaginal smears at postnatal week (PNW) 8-9 and PNW 19-20. To determine the preovulatory gonadotropin surge, blood samples were collected from the tail vein without anethesia at 1100 and $1600 \mathrm{hr}$ of proestrus in female rats at PNW 20, trunk blood was taken and centrifuged at 3,000 rpm for $15 \mathrm{~min}$ at $4^{\circ} \mathrm{C}$. The serum was collected and stored at $-20^{\circ} \mathrm{C}$ until assayed for serum estradiol, LH, and FSH. Blood samples were also taken from males at PNW 20 for the measurement of serum LH, FSH and testosterone.

At PNW 20-21, copulatory behavior tests in both males and females were performed in the dark room at $1900 \mathrm{hr}$, and recorded with a VCR system (DCR-TRV20 digital video camera, Sony, Tokyo, Japan). In each behavioral test, a sexually inexperienced male was placed in a plastic cage $(40 \times 22 \times 18 \mathrm{~cm})$. After $2 \mathrm{hr}$ adaptation period, a highly estrous ovariectomized female, primed with a subcutaneous estradiol silastic tube (70\% cholesterol/30\% $17 \beta$-estradiol) for 5 days and injected with $1 \mathrm{mg}$ progesterone $6 \mathrm{hr}$ before the test, was introduced into the cage. Male sexual behavior was observed for $30 \mathrm{~min}$ after the introduction of the female. The female was replaced by another similarly prepared female every $10 \mathrm{~min}$ to eliminate the influence of partner affinity. The following standard measures of male copulatory behavior were recorded: frequency of mount, intromission and ejaculation during the $30 \mathrm{~min}$; and interval between first ejaculation and subsequent mount (postejaculation interval, PEI). Regarding the frequency of mount and intromission, when the male ejaculated 
during the $30 \mathrm{~min}$ of the experimental period, the number of mounts and intromission from the time of female introduction to the first ejaculation was converted into the number per $30 \mathrm{~min}$. As for females, lordosis reflex was examined on the day of proestrus by sexually experienced vasectomizedmales. Lordosis quotient (LQ) was recorded as the number of lordosis reflex/10 mounts by males $\times 100(\%)$.

\section{Hormone assays}

Serum concentrations of testosterone and estradiol by testosterone and estradiol enzyme-immunoassays (EIA) kits (Cayman Chemical, MI, USA), LH and FSH by rat LH and FSH EIA systems (Amersham Pharmacia Biotech, Buckinghamshire, UK), were measured, respectively, according to the manufacturer's

Mount

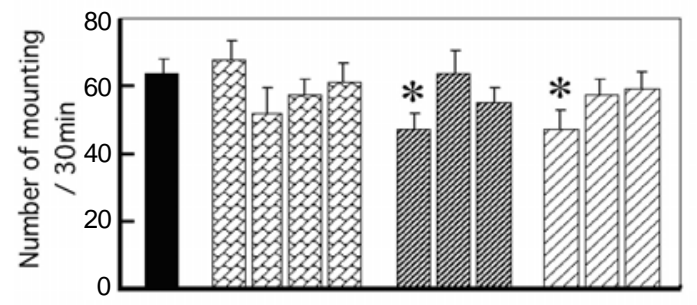

Ejaculation

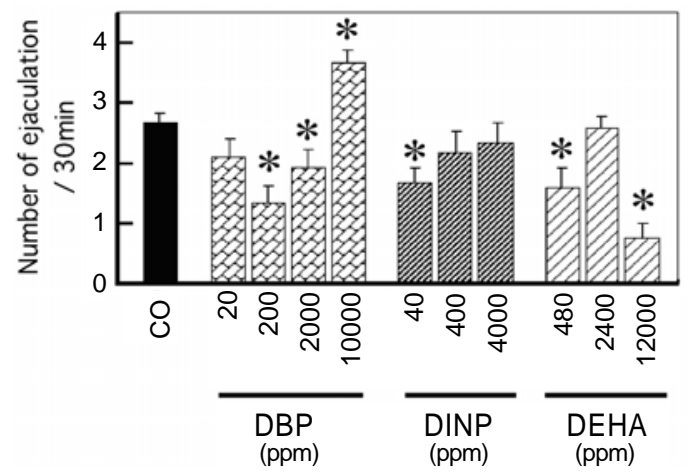

protocol.

\section{Statistical analysis}

Statistical analyses were conducted using StatView (version J5, Abacus Concepts, Inc.). A one-way analysis of variance and Dunnett's test were used to determine differences between treated and control groups. Differences were considered statistically significant at $\mathrm{P}<0.05$.

\section{RESULTS}

1. Effects of perinatal exposure on male reproductive function

Fig. 2 shows the numbers of sexual behaviors in male rats. All of the control rats showed

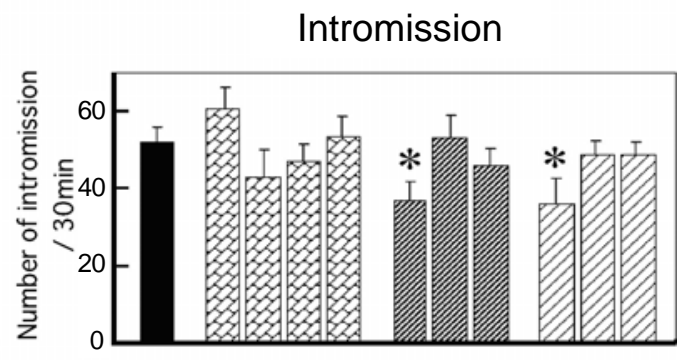

PEI

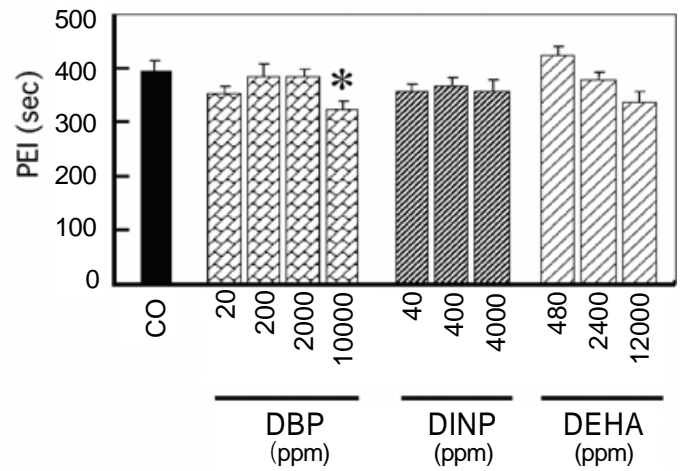

Fig. 2. The frequency of copulatory behaviors during $30 \mathrm{~min}$ in male rats at postnatal week 20 . The rats exposed to DBP, DINP and DEHA from gestational day 15 to postnatal day 21 . Data represent mean \pm SE., $n=6-12$ rats four litters per group. $C O$, control diet; DBP, di-n-butyl phthalate; DINP, diisononyl phthalate; DEHA, di-2-ethylhexyl phthalate; PEI, post ejaculation interval. $*, \mathrm{P}<0.05$ vs. CO. 
normal copulatory behavior. The perinatal exposure to DBP, DINP or DEHA at any dose did not affect the number of mount and intromission, but in $40 \mathrm{ppm}$ DINP- and $480 \mathrm{ppm}$ DEHA-exposed rats, the numbers of mount and intromission were significantly decreased compared with those of control animals. Although not significant for mount and intromission at $200 \mathrm{ppm}$ or 2,000 ppm DBPand 12,000 ppm DEHA-exposed, the numbers of ejaculations were significantly decreased at these doses. The rats showing significantly decreased numbers of mounts and intromissions at $40 \mathrm{ppm}$ DINP- and 480 ppm DEHA-exposed also showed significantly decreased ejaculation at these doses. On the other hand, there was no significant difference in PEI between control and chemicals exposed-groups (excluding 10,000 ppm DBP-exposed groups).

Serum levels of LH and FSH in these chemicals exposed rats at PNW 20 were comparable between control and all dose groups (Fig. 3). Although LH and FSH were measured concurrently on PNW 20,
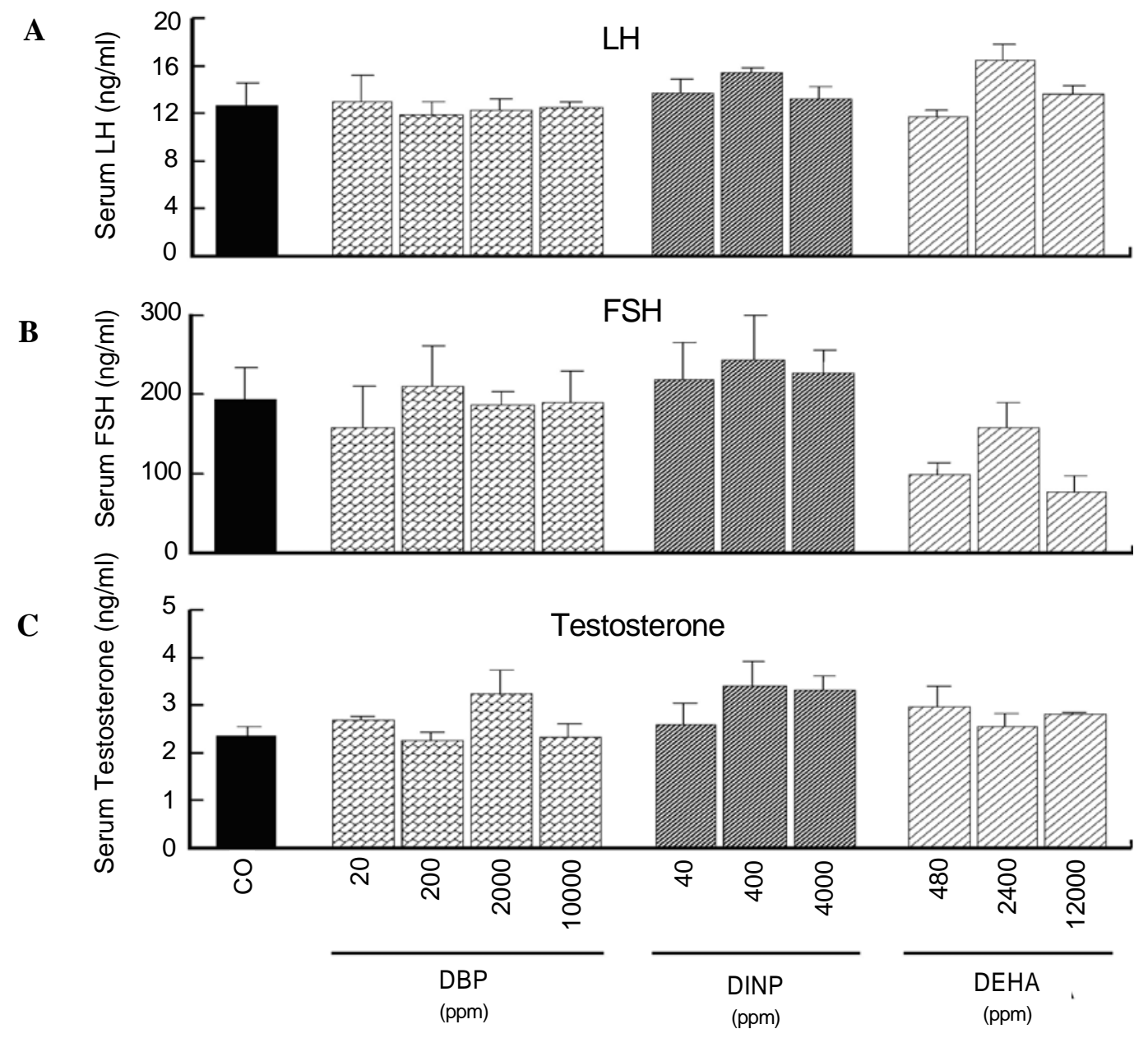

Fig. 3. Serum LH (A), FSH (B) and testosterone (C) levels in male rats at postnatal week 20. The rats exposed to DBP, DINP and DEHA from gestational day 15 to postnatal day 21. Data represent mean $\pm \mathrm{SE}$., $n=6-12$ rats four litters per group. $\mathrm{CO}$, control diet; $\mathrm{DBP}$, di-n-butyl phthalate; DINP, diisononyl phthalate; DEHA, di-2-ethylhexyl phthalate. 
no significant changes in gonadotropins levels were identified following perinatal exposure to these chemicals.

2. Effects of perinatal exposure on female reproductive function

The occurrence of lordosis behavior, preovulatory LH and FSH levels were determined in the afternoon of the day predicted as the proestrus in control and DBP, DINP or DEHA-exposed rats. In the neonatal EB- or TP-treated group, these parameters were evaluated on the day of vaginal estrus because all the animals showed persistent estrus. All of the control rats showed normal lordosis reflex. In these chemical treated rats, the mean LQs were significantly suppressed at all the doses used and in EB- or TP-treated animals (Fig. 4A). Estrous cyclicity was monitored by microscopic examination of vaginal cytology. All the control rats showed regular cycles, whereas EB- or TP-treated animals showed persistent vaginal estrus. However, female rats exposed to any dose of DBP, DINP or DEHA showed regular estrous cyclicity (Fig. 4B). As shown in Fig. 5, serum LH and FSH levels at $1600 \mathrm{hr}$ on proestrus between control and chemical exposed-rats were not significant.

A

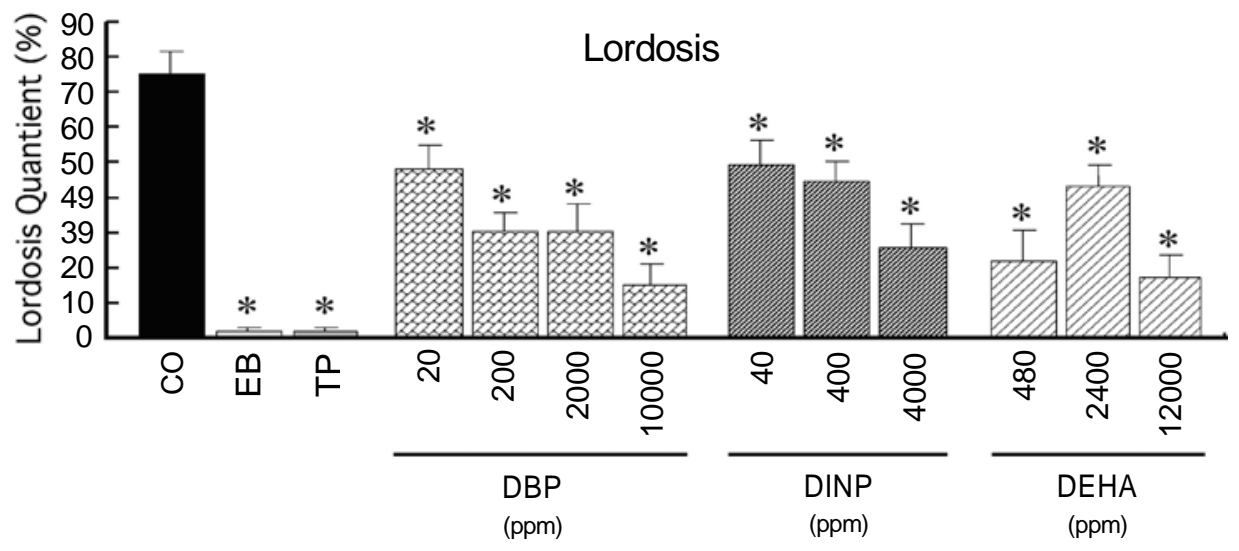

B

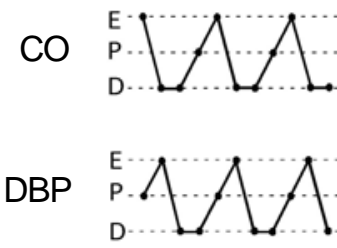

Estrous cycles

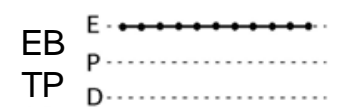

DEHA
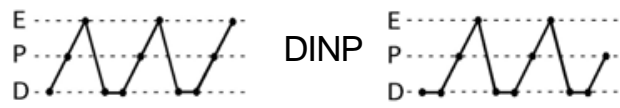

Fig. 4. Lordodsis quotient of female rats (A), and representative pattern of estrous cycles in each group (B) at postnatal week 8 or 20. The occurrence of lordosis behavior was determined in the evening of the predicted as the proestrus. In the neonatal EB or TP-treated group, lordosis behavior was evaluated on the day of vaginal estrus. The rats exposed to DBP, DINP and DEHA from gestational day 15 to postnatal day 21 . Data represent mean \pm SE., $n=6-12$ rats four litters per group. CO, control diet; EB, estradiol benzoate; TP, testosterone propionate; E, estrus; P, proestrus; D, diestrus; DBP, di-n-butyl phthalate; DINP, diisononyl phthalate; DEHA, di-2-ethylhexyl phthalate. $*, \mathrm{P}<0.05$ vs. CO. 


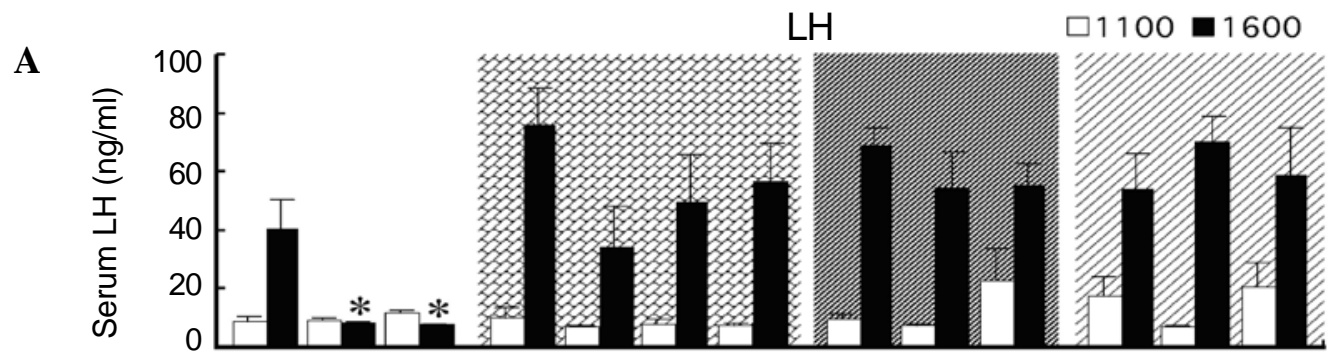

$\mathrm{FSH}$
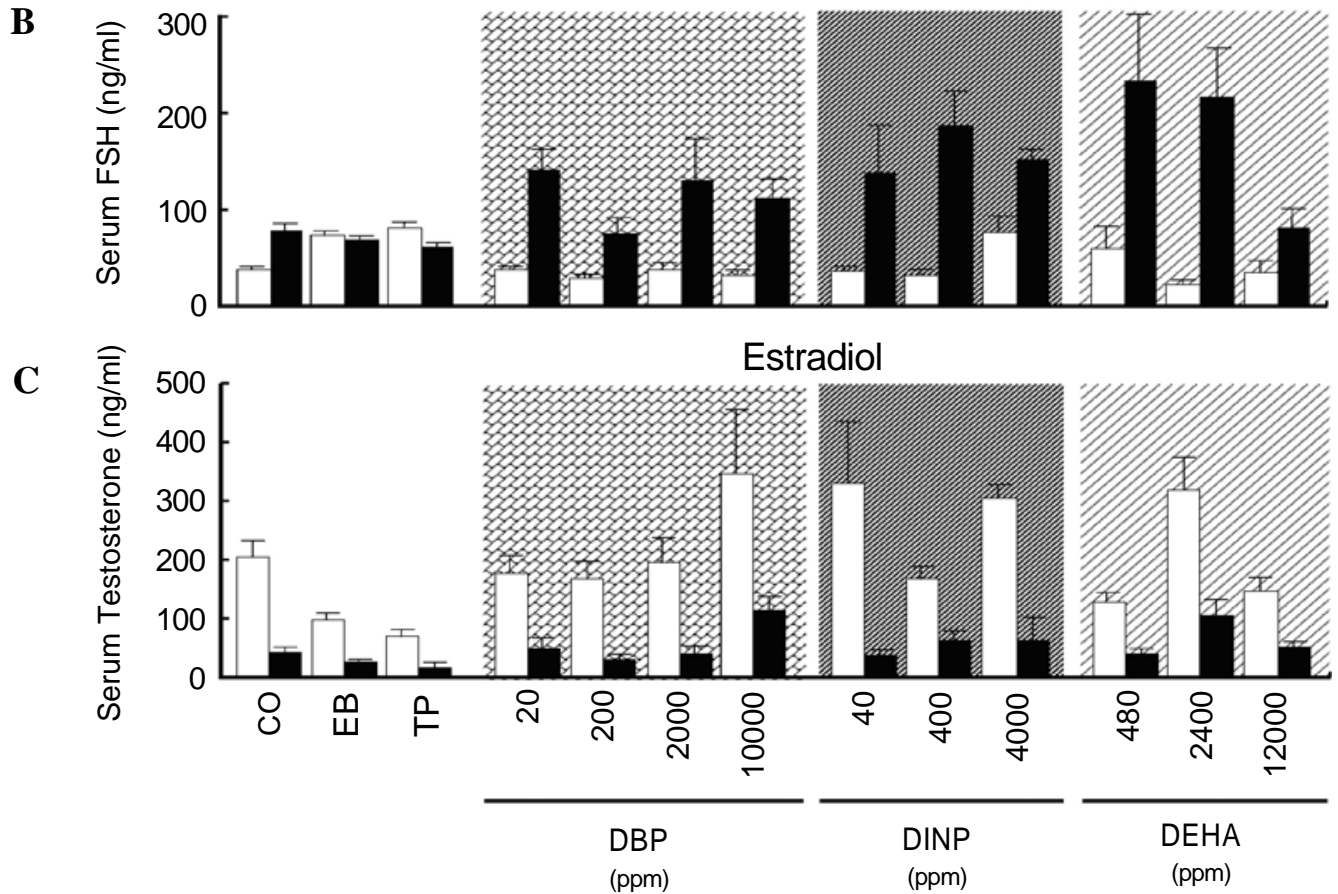

Fig. 5. Serum LH (A), FSH (B) and estradiol (C) levels in female rats at $1100 \mathrm{hr}$ and 1600 $\mathrm{hr}$, at postnatal week 20. The gonadotropin levels were determined on the day predicted as the proestrus. In the neonatal EB or TP-treated group, gonadotropin and estradiol levels were evaluated on the day of vaginal estrus. The rats exposed to DBP, DINP and DEHA from gestational day 15 to postnatal day 21. Data represent mean $\pm S E$., $n=6-12$ rats four litters per group. $C O$, control diet; $E B$, estradiol benzoate; TP, testosterone propionate; DBP, di-n-butyl phthalate; DINP, diisononyl phthalate; DEHA, di-2-ethylhexyl phthalate. *, P<0.05 vs. CO.

\section{DISCUSSION}

Mylchreest et al. (1998) and Gray et al. (1999) have reported that some phthalates can exhibit antiandrogenic-like activity, due to abnormal testicular development, if exposure occurs during gestation and lactation. However, in the two- generation DINP dietary study, Waterman et al. (2000) observed that there were no changes in any of the classic reproductive parameters, i.e. mating, male or female fertility, fecundity, or length of gestation in Sprague-Daweley rats. Although we analyzed only sex steroid (testosterone and estradiol) and gonadotropin (LH and FSH surge) 
as reproductive parameters on PNW 20, consistently with the results obtained by Waterman et al. (2000), there were no negative effects, such as depression of gonadotropin surge and reduction of sex hormone, generally thought to be effect of EDCs. However, EB or TP treatment suppressed the occurrence of lordosis behavior and gonadotropin surge, which has been considered to result from the masculinization of the brain by estrogen (Arnold and Gorski, 1984; MacLusky and Naftolin, 1981; McEwen et al., 1977).

On the other hand, inhibitory influences on male sexual behaviors were observed by perinatal exposure to these chemicals at several doses. All the mount, intromission and ejaculation frequency were suppressed by the lowest doses of DINP and DEHA, and ejaculation was also suppressed by the highest dose of DEHA. The suppressive effect of DEHA on male sexual behavior was probably due to the decrease in granulin (grn) gene expression in the hypothalamus observed at PND 7 by DEHA at these doses, since a decrease in grn mRNA by the infusion of an antisense oligodeoxynucleotide of grn gene into the third ventricle of male rats at PND 2 suppressed male sexual behavior after maturation (Suzuki et al., 2000). Also, although grn and/or p130 genes may at least partially related to the brain sexual differentiation resulting in increase and/or decrease sexual behavior parameters, many more genes, which has different expression levels in hypothalamus between sexes (Yonehara et al., 2002), could be responsible for brain sexual differentiation. On the other hand, Kakeyama et al. (2003) recently reported that perinatal exposure of male rats to 2, 3, 7, 8-tetrachlorodibenzo-pdioxin (TCDD) resulted in the decrease of the frequency of mounts and intromissions without affecting the volume of sexually dimorphic nucleus of preoptic area (SDN-POA). These results may suggest that TCDD affects another region of hypothalamus aside from the region know to show sexual dimorphism. Coolen et al. (1997) also demonstrated that ejaculation-specific circuit exists within the larger circuitry for male sexual behavior by using Fos immunoreactivity. Taken together, our results suggest another possibility that these chemicals may directly affect the ejaculation-specific circuit within brain during critical period.

On the other hand, the reason why the effects of the chemicals were not dose-dependent is currently unclear, but similar non-dose-dependent effect of DBP has been reported by others (Masutomi et al., 2003). DBP at 200 and 2,000 ppm decreased ejaculation frequency, while that at 10,000 ppm increased ejaculation frequency and shortened PEI, without affecting mount and intromission frequency. DBP at low doses increased p130 mRNA in neonatal male hypothalamus and that at higher doses increased grn mRNA in neonatal female hypothalamus (data not shown). Although not significantly, DBP at the highest dose also increased grn mRNA in male hypothalamus. These changes in hypothalamic gene expression caused by perinatal exposure to DBP may account for the different effects of it on ejaculation after maturation. However, the possibility that other factors rather than grn and p130 are also affected by perinatal exposure to the chemicals and involved in the decrease in sexual behavior in males after maturation also currently cannot be ruled out. Further studies are needed to clarify the presice mechanisms underlying the actions of pthalate/adipate esters on sex steroid-dependent gene expression in the hypothalamus.

The recurrence of estrous cycles was regarded as one of the manifestations of sexual dimorphic function of brain. It had been demonstrated that perinatal administration of sex steroids induces persistent vaginal estrus associated with the lack of estrous cyclicity in rats (Barraclough and Gorski, 1961). This was also demonstrated in the 
present study. Mylchreest et al. (1998) and Masutomi et al. (2003) observed that perinatal exposure to DBP or DINP did not affect estrous cyclicity after maturation. Similarly, in the present study, irregular estrous cycles were not observed in rats perinatally exposed to DBP and DINP as well as DEHA. Also, these results, pattern of normal gonadotropin surge, suggest that DBP, DINP and DEHA exposure dose not likely alter function of hypothalamo-pituitary- gonadal (HPG) axis, namely, induction of ovulation that was caused by gonadotropin-releasing hormone and LH surges, which were induced by positive feedback action of estrogen. On the other hand, estrogen acted within the ventromedial nucleus of hypothalamus $(\mathrm{VMH})$ to facilitate lordosis, the posture adopted by the female rat in response to mounting male during mating (Carrer et al., 1973; Meisel et al., 1987; Pfaff, 1989). Taken together, in the present study, despite normal estrous cycles and ovulation, lordosis reflex was suppressed significantly, implying that these chemicals directly act on the certain region of VMH. Actually, mating increases the expression of Fos in the VMH of female rats (Flanagan-Cato and McEwen, 1995; Tetel et al., 1993; Yang et al., 1999) and, Calizo and Flanagan-Cato (2003) had also recently suggested that the $\mathrm{VMH}$ contained at least three lordosis-relevant neural populations. On the other hand, high expressions of grn and p130 genes were observed in VMH and arcuate (ARC) (Suzuki et al., 1998; Yonehara et al., 2002), which contain abundant ER, and these chemicals were also capable of binding to ER (Andersen et al., 1999; Harris et al., 1997; Jobling et al., 1995; Zacharewski et al., 1998). Therefore, the chemicals used in the present study may directly affect the organization of neuronal circuits in the $\mathrm{VMH}$, but not MPOA, during the processes of the sexual differentiation of the brain.

In conclusion, these chemicals may act directly on discrete regions of the hypothalamus regulating sexual behaviors, but not regulating gonadotropin secretion, thereby affect sexual differentiation of the brain with a resultant decrease in sex-specific behaviors in adulthood.

\section{ABSTRACT}

Phthalate esters that are used as plasticizers and also found at low levels in foods such as dairy products are often mentioned as suspected endocrine disrupters. The purpose of the present study is to elucidate whether perinatal exposure to di-n-butyl phthalate (DBP), diisononyl phthalate (DINP) and di-2-ethylhexyl adipate (DEHA) affects several aspects of reproductive function in rats especially sexual differentiation of the brain. To this end, the dams were provided with pulverized soy-free diet containing 20, 200, 2,000 and $10,000 \mathrm{ppm}$ of DBP, 40, 400, 4,000 and 20,000 ppm of DINP, or 480, 2,400 and 12,000 ppm of DEHA from gestational day (GD) 15 to postnatal day (PDN) 21, the day of weaning, and serum sex steroid hormone, gonadotropin levels and sexual behaviors after maturation were assessed. At Postnatal week (PNW) 20-21, serum levels of sex steroids and gonadotropins in both male and female rats, as well as estrous cyclicity in females, were not changed by perinatal exposure to DBP, DINP and DEHA, indicating that these chemicals did not affect sexual differentiation of the brain controlling the endocrine system of hypothalamo-pituitary-gonadal (HPG) axis. On the other hand, inhibitory influences on sexual behaviors, especially on ejaculation in males and lordosis in females, were observed by perinatal exposure to these chemicals. These results suggest that these chemicals may act directly on discrete regions of the hypothalamus regulating sexual behaviors, but not regulating gonadotropin secretion, thereby affect sexual differentiation of the brain with a resultant decrease in sex-specific behaviors 
in adulthood.

(Key words : Adipate, Gonadotropin, Phthalate, Sexual behavior, Sex steroid hormone)

\section{ACKNOWLEDGMENTS}

This work was supported in part by a Grant-inAid from the Ministry of Health, Labor and Welfare of Japan (Research for Food and Chemical Safety) and a Grant-in-Aid for Scientific Research from the Japan Society for the Promotion of Science.

\section{REFERENCES}

1. Andersen HR, Andersson AM, Arnold SF, Autrup $\mathrm{H}$, Barfoed M, Beresford NA, Bjerregaard P, Christiansen LB, Gissel B., Hummel R, Jorgensen EB, Korsgaard B, Le Guevel R, Leffers H, McLachlan J, Moller A, Nielsen JB, Olea N Oles, Karasko A, Pakdel F, Pedersen KL, Perez P, Skakkeboek NE, Sonnenschein C, Soto AM, Sumpter JP, Thorpe SM. and Grandjean P. 1999. Comparison of short-term estrogenicity tests for identification of hormone-disrupting chemicals. Environ. Health. Perspect. 107 Suppl. 1:89-108.

2. Arcadi FA, Costa C, Imperatore C, Marchese A, Rapisarda A, Salemi M, Trimarchi GR. and Costa G. 1998. Oral toxicity of bis(2-ethylhexyl) phthalate during pregnancy and suckling in the Long-Evans rat. Food Chem. Toxicol.; 36:963-970.

3. Arnold AP. and Gorski RA. 1984. Gonadal steroid induction of structural sex differences in the central nervous system. Annu. Rev. Neurosci. 7:413-442.

4. Barlow S, Kavlock RJ, Moore JA, Schantz SL, Sheehan DM, Shuey DL. and Lary JM. 1999. Teratology Society Public Affairs Committee position paper: developmental toxicity of endocrine disruptors to humans. Teratology 60:365-375.

5. Barraclough CA. and Gorski RA. 1961. Evidence that the hypothalamus is responsible for androgen- induced sterility in the female rat. Endocrinology 68:68-79.

6. Carrer H, Asch G. and Aron C. 1973. New facts concerning the role played by the ventromedial nucleus in the control of estrous cycle duration and sexual receptivity in the rat. Neuroendocrinology 13:129-138.

7. Calizo LH. and Flanagan-Cato LM. 2003. Hormonal-neural integration in the female rat ventromedial hypothalamus: triple labeling for estrogen receptor-alpha, retrograde tract tracing from the periaqueductal gray, and mating induced Fos expression. Endocrinology 144:5430-5440.

8. Colborn T, vom Saal FS. and Soto AM. 1993. Developmental effects of endocrine-disrupting chemicals in wildlife and humans. Environ. Health. Perspect. 101:378-384.

9. Colborn T. 1996. Our Stolen Future. 1 ed. Penguin Group, USA.

10. Coolen LM, Olivier, B, Peters HJ. and Veening JG. 1997. Demonstration of ejaculation- induced neural activity in the male rat brain using 5-HT1A agonist 8-OH-DPAT. Physiol. Behav. 62:881-891.

11. Flanagan-Cato LM. and McEwen BS. 1995. Pattern of Fos and Jun expression in the female rat forebrain after sexual behavior. Brain Res. 673: 53-60.

12. Gray LE. Jr., Wolf C, Lambright C, Mann P, Price M, Cooper RL. and Ostby J. 1999. Administration of potentially antiandrogenic pesticides (procymidone, linuron, iprodione, chlozolinate, p,p'-DDE, and ketoconazole) and toxic substances (dibutyl- and diethylhexyl phthalate, PCB 169, and ethane dimethane sulphonate) during sexual differentiation produces diverse profiles of reproductive malformations in the male rat. Toxicol. Ind. Health. 15:94-118.

13. Gray LE. Jr., Ostby J, Furr J, Price M, Veeramachaneni DN. and Parks L. 2000. Perinatal exposure to the phthalates DEHP, BBP, and DINP, but not DEP, DMP, or DOTP, alters 
sexual differentiation of the male rat. Toxicol. Sci. 58:350-365.

14. Gray LE, Ostby J, Furr J, Wolf CJ, Lambright C, Parks L, Veeramachaneni DN, Wilson V, Price M, Hotchkiss A, Orlando E. and Guillette L. 2001. Effects of environmental antiandrogens on reproductive development in experimental animals. Hum. Reprod. Update 7:248- 264.

15. Harris CA, Henttu P, Parker MG. and Sumpter JP. 1997. The estrogenic activity of phthalate esters in vitro. Environ. Health. Perspect. 105:802811.

16. Jobling S, Reynolds T, White R, Parker MG. and Sumpter JP. 1995. A variety of environmentally persistent chemicals, including some phthalate plasticizers, are weakly estrogenic. Environ. Health. Perspect. 103:582-587.

17. Kakeyama M, Sone H, Miyabara Y. and Tohyama C. 2003. Perinatal exposure to 2, 3, 7, 8tetrachlorodibenzo-p-dioxin alters activity-dependent expression of BDNF mRNA in the neocortex and male rat sexual behavior in adulthood. Neurotoxicology 24:207-217.

18. Lington AW, Bird MG, Plutnick RT, Stubblefield WA. and Scala, RA. 1997. Chronic toxicity and carcinogenic evaluation of diisononyl phthalate in rats. Fundam. Appl. Toxicol. 36:79-89.

19. MacLusky NJ. and Naftolin F. 1981. Sexual differentiation of the central nervous system. Science 211:1294-1302.

20. Masutomi N, Shibutani M, Takagi H, Uneyama C, Takahashi N. and Hirose M. 2003. Impact of dietary exposure to methoxychlor, genistein, or diisononyl phthalate during the perinatal period on the development of the rat endocrine/ reproductive systems in later life. Toxicology 192:149-170.

21. McEwen BS, Lieberburg I, Chaptal C. and Krey LC. 1977. Aromatization: important for sexual differentiation of the neonatal rat brain. Horm. Behav. 9:249-263.

22. Meisel RL, Dohanich GP, McEwen BS. and Pfaff
DW. 1987. Antagonism of sexual behavior in female rats by ventromedial hypothalamic implants of antiestrogen. Neuroendocrinology 45:201-207.

23. Mylchreest E, Cattley RC. and Foster PM. 1998. Male reproductive tract malformations in rats following gestational and lactational exposure to Di(n-butyl) phthalate: an antiandrogenic mechanism? Toxicol. Sci. 43:47-60.

24. Mylchreest E, Sar M, Cattley RC. and Foster PM. 1999. Disruption of androgen-regulated male reproductive development by di(n-butyl) phthalate during late gestation in rats is different from flutamide. Toxicol. Appl. Pharmacol. 156:81-95.

25. Mylchreest E, Wallace DG, Cattley RC. and Foster PM. 2000. Dose dependent alterations in androgen-regulated male reproductive development in rats exposed to $\mathrm{Di}$ (n-butyl) phthalate during late gestation. Toxicol. Sci. 55:143-151.

26. Page BD. and Lacroix GM. 1995. The occurrence of phthalate ester and di-2-ethylhexyl adipate plasticizers in Canadian packaging and food sampled in 1985-1989: a survey. Food Addit. Contam. 12:129-151.

27. Petersen JH. and Breindahl T. 1998. Specific migration of di-(2-ethylhexyl)adipate (DEHA) from plasticized PVC film: results from an enforcement campaign. Food Addit. Contam. 15:600-608.

28. Pfaff DW. 1989. Patterns of steroid hormone effects on electrical and molecular events in hypothalamic neurons. Mol. Neurobiol. 3:135-154.

29. Sharman M, Read WA, Castle L. and Gilbert J. 1994. Levels of di-(2-ethylhexyl) phthalate and total phthalate esters in milk, cream, butter and cheese. Food Addit. Contam. 11:375-385.

30. Sharpe RM, Fisher JS, Millar MM, Jobling S. and Sumpter JP. 1995. Gestational and lactational exposure of rats to xenoestrogens results in reduced testicular size and sperm production. Environ. Health. Perspect. 103:1136-1143.

31. Suzuki M, Yoshida S, Nishihara M. and Takahashi M. 1998. Identification of a sex steroid-inducible gene in the neonatal rat hypothalamus. Neurosci. 
Lett. 242:127-130.

32. Suzuki M, Bannai M, Matsumuro M, Furuhata Y, Ikemura R, Kuranaga E, Kaneda Y, Nishihara M. and Takahashi M. 2000. Suppression of copulatory behavior by intracerebroventricular infusion of antisense oligodeoxynucleotide of granulin in neonatal male rats. Physiol. Behav. 68:707-713.

33. Tetel MJ, Getzinger MJ. and Blaustein JD. 1993. Fos expression in the rat brain following vaginalcervical stimulation by mating and manual probing. J. Neuroendocrinol 5:397-404.

34. Toppari J, Larsen JC, Christiansen P, Giwercman A, Grandjean P. and Guillette Jr LJ. 1996. Male reproductive health and environmental xenoestrogens. Environ. Health. Perspect. 104 Suppl. 4, pp 741-803.

35. Waldron AC. and Naber EC. 1974. Importance of feed as an unavoidable source of pesticide contamination in poultry meat and eggs. 2 . Residues in eggs and tissues. Poult. Sci. 53:14281435.

36. Waterman SJ, Keller LH, Trimmer GW, Freeman JJ, Nikiforov AI, Harris SB, Nicolich MJ. and McKee RH. 2000. Two-generation reproduction study in rats given di-isononyl phthalate in the diet. Reprod. Toxicol. 14:21-36.
37. Wine RN, Li LH, Barnes LH, Gulati DK. and Chapin RE. 1997. Reproductive toxicity of di-nbutylphthalate in a continuous breeding protocol in Sprague-Dawley rats. Environ. Health. Perspect. 105:102-107.

38. Yang S, Lee Y. and Voogt JL. 1999. Fos expression in the female rat brain during the proestrous prolactin surge and following mating. Neuroendocrinology 69:281-289.

39. Yonehara K, Suzuki M. and Nishihara M. 2002. Sex-related differences in gene expression in neonatal rat hypothalamus assessed by cDNA microarray analysis. Endocr. J. 49:131-137.

40. Yonehara K, Suzuki M, Yamanouchi K. and Nishihara M. 2000. Androgen induces p130 mRNA expression in the neonatal rat hypothalamus. Neurosci. Lett. 334:107-110.

41. Zacharewski TR, Meek MD, Clemons JH, Wu ZF, Fielden MR. and Matthews JB. 1998. Examination of the in vitro and in vivo estrogenic activities of eight commercial phthalate esters. Toxicol. Sci. 46:282-293.

(접수일자 : 2006. 9. 4. / 채택일자 : 2006. 10. 18.) 